\title{
SENSOR FIBER OPTIK BF4R SEBAGAI PENDETEKSI WARNA PADA ALAT PENSORTIR BOBBIN BENANG BERBASIS PLC OMRON CP1E-N 30 DRA DAN SCADA
}

\author{
Akbar Tandu Fasila, Heru Winarno \\ Program Studi Diploma III Teknik Elektro \\ Fakultas Teknik Universitas Diponegoro
}

\begin{abstract}
Akbar Tandu Fasila, Heru Winarno, in this paper explain that in the modern era, the progress of technology is very important in their daily lives, particularly in the industrial sector. Changes to automated manual system is very developed in order to achieve the maximum point of production and reduce the level of error that often occur in manual systems. It also affects the yarn spinning industry yanl, $g$ now utilize the tools pensortir menerapkkan yarn bobbins with pneumatic system, PLC and SCADA. Planning tool making this sort can not be separated from the fiber optic sensor for identifying the color on each bobbin thread through the intensity of light that is captured by a fiber optic sensor tersbut. The workings of the system works and consists of two cylinders Pneumatic that serves as the actuator, two sensors fiber optics for detecting the light intensity on the bobbin thread, one unit PLC OMRON CPIE-N 30 DRA as the main controller systems, and SCADA as the monitoring system works.
\end{abstract}

Keywords: Bobbin Thread, PLC, SCADA, Fiber Optic Sensor.

\section{PENDAHULUAN \\ Latar Belakang}

Pada perusahaan tekstil terdapat suatu proses produksi yang menggunakan warna bobbin benang sebagai tanda jenis benang yang akan di gulung. Pada 1 (satu) line mesin pemintal benang maksimal terdapat 3 (tiga) pintal benang yang setelah dipintal bobbin bercampur. Kurangnya pengetahuan akan sistem pneumatik dan PLC terutama yang di lengkapi dengan sistem SCADA, mengakibatkan masih ada sebagian industri tekstile masih menggunakan sistem manual. Karena pentingnya alat ini, maka dibuatlah inovasi alat yang bekerja secara otomatis dengan memanfaatkan PLC sebagai kontrolnya, sistem SCADA untuk monitoringnya, serta sistem pneumatik sebagai mekaniknya.

\section{Perumusan Masalah}

Permasalahan yang akan di bahas dalam penelititan ini :

- Bagaimana Sensor Intensitas Cahaya ( BF4 R ) dapat membedakan warna pada bobbin benang.

- Bagaimana sistem Kerja Pneumatik pada proses pensortiran bobbin benang.

- Bagaimana sistem PLC (Progamable Logic Control) dalam mengubah sistem konvensional menjadi otomatis pada proses pensortiran bobbin benang.

\section{Tujuan Pembuatan Alat} adalah :

Tujuan dari penelititan yang dilakukan ini

- Mengetahui Penggunaan Sensor Fiber Optik BF4R dalam membedakan warna pada alat pensortir bobbin benang.
- Mengetahui prinsip kerja sistem Pneumatik sebagai aktuator Proses pensortir warna bobbin benang

- Membuat Program pada Programmable Logic Controller sebagai pengendali utama pada pembuatan alat pensortir warna bobbin benang Berbasis PLC dan SCADA.

\section{LANDASAN TEORI}

Programmable Logic Control / PLC

PLC ( Programmable Logic Control) merupakan sebutan dari sebuah pengontrol yang dapat diprogram. Pengontrol yang dapat diprogram merupakan computer yang dirancang untuk penggunaan pada mesin, dan dirancang untuk bekerja di lingkungan industri serta memiliki input output khusus dan pengendali bahasa pemrograman. Bagian-bagian PLC adalah sebagai berikut :

- Unit Catu Daya

Catu daya atau power supply adalah suatu rangkaian yang berfungsi sebagai sumber daya untuk mengoperasikan rangkaian yang lain.

- Unit Prosesor Pusat (CPU)

Unit ini berfungsi untuk mengambil dan mengolah data instruksi dari memori, mengkodekannya dan kemudian mengoperasikan instruksi tersebut dalam bentuk sinyal kontrol untuk dikirimkan kepada modul masukan dan keluaran.

- Unit Memori

Unit ini berfungsi sebagai penyimpan instruksiinstruksi $P L C$, biasanya fungsi-fungsi khusus $P L C$.Dengan demikian memori adalah bagian penting dari $P L C$.

- Modul Masukan dan Keluaran ( $I / O$ ) 
Modul Input dan Output merupakan peralatan elektronik yang berfungsi sebagai perantara atau penghubung antara $C P U$ dengan peralatan input dan output luar.

- Peralatan Peripheral

Adalah peralatan-peralatan yang dapat dihubungkan dengan PLC guna membantu dalam pengoperasiannya. Peralatan ini meliputi peralatan pemograman, printer, media luar penyimpan data (external storage media), interface adapter dan sebagainya.

Jenis $P L C$ yang digunakan adalah CP1E. Unit $C P U$ dari CP1E yang terbagi menjadi tiga jenis sesuai dengan terminal input - outputnya", yaitu :

- CP1E $20 \mathrm{I} / O$ (terdiri dari 12 input \& 8 output)

- CP1E $30 \mathrm{I} / O$ (terdiri dari 18 input \& 12 output)

- CP1E 40 I/O (terdiri dari 24 input \&16 outpu )

Dari keempat jenis unit $C P U$ CP1Edi atas yang dipakai dalam pembuatan alat ini adalah jenis CPIE N30DR-A dan diprogram dengan $C x$ programmer, dari gambar 1 dapat diketahui bagianbagian komponen dari CPIE N3ODR-A.

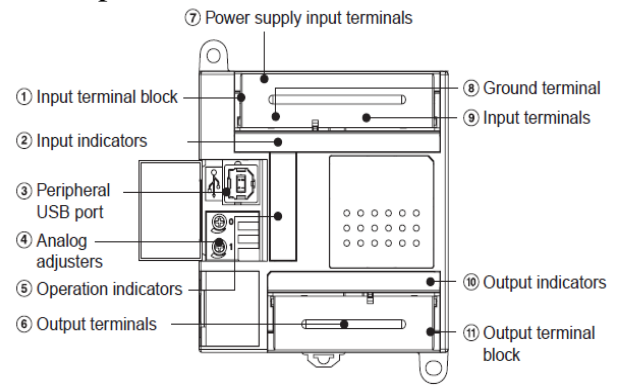

Gambar 1. Komponen-komponen yang ada dalam PLC CPIE N30DR-A

\section{SCADA}

SCADA merupakan singkatan dari Supervisory Control and Data Acquisition, merupakan pendukung utama dalam sistem ketenagalistrikan, baik pada sisi pembangkit, transmisi, maupun distribusi. Adanya sistem SCADA memudahkan operator untuk memantau keseluruhan jaringan tanpa harus melihat langsung ke lapangan.

Suatu pusat pengendali yang sederhana biasanya mempunyai sistem perangkat keras seperti gambar 2.

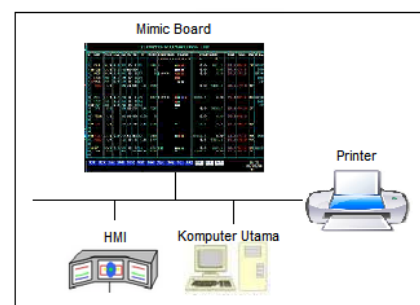

Gambar 2. Komponen Perangkat Keras dari SCADA

\section{- Komputer Utama}

Komputer Utama mempunyai fungsi sebagai berikut :

○ Mengatur komunikasi dirinya sendiri dengan RTU.

- Mengirim dan menerima data dari RTU kemudian menterjemahkannya kedalam bentuk informasi yang dapat dimengerti oleh user.

- Mendistribusikan informasi tersebut ke Human Machine Interface, Mimic Board dan Printer Logger dan menyimpan informasi tersebut.

- Memanajemen semua peralatan pusat kontrol yang lain.

- Human Machine Interface

Sistem Human Machine Interface meliputi semua peralatan yang dipergunakan untuk menyampaikan informasi kepada operator dan dapat dipakai oleh operator untuk mengoperasikan sistem antara lain : Video Display Unit, Keyboard controller dan mouse.

\section{- $\quad$ Mimic Board}

Mimic Board merupakan peralatan yang mempunyai fungsi untuk menampilkan sistem yang dikontrol dalam bentuk diagram statik, display angka hasil pengukuran serta display status.

\section{- Printer}

Printer merupakan peralatan yang mempunyai fungsi untuk mencetak informasi, data, gambar, dan grafik yang didapat dari komputer utama.

\section{Sistem Pneumatik}

Perkataan pneumatik berasal bahasa Yunani "pneuma" yang berarti "napas" atau "udara". Jadi pneumatik berarti terisi udara atau digerakkan oleh udara mampat. Pneumatik merupakan cabang teori aliran atau mekanika fluida dan tidak hanya meliputi penelitian aliran-aliran udara melalui suatu sistem saluran, yang terdiri atas pipa-pipa, selang-selang, gawai dan sebagainya, tetapi juga aksi dan penggunaan udara mampat.

Sistem udara tekan (pneumatic) terdiri dari komponen utama berikut :

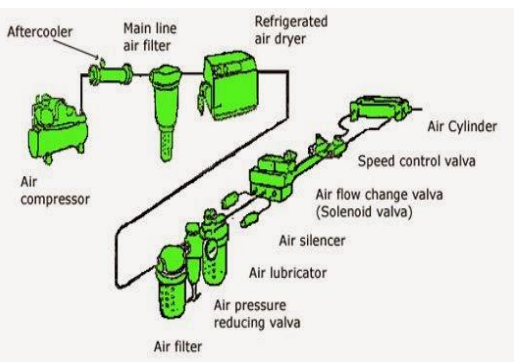

Gambar 3. Unit pengaturan udara kempa

Kompresor adalah peralatan yang dipergunakan untuk menghasilkan udara kempa, udara akan diserap dan dimampatkan oleh kompresor yang digerakkan oleh motor listrik. 
After Cooler, salah satu alat yang digunakan untuk mendinginkan udara kempa dengan menggunakan air atau media lain yang dapat berfungsi sebagai pendingin udara kempa.

Main Line Air Filter, peralatan yang berfungsi untuk mengeleminir debu dan air serta kandungan minyak pada udara kempa.

Refrigerated Air Dryer, alat ini berfungsi untuk mengeringkan udara basah atau udara yang masih mengandung embun atau titik air, sehingga dapat menghasilkan udara kempa yang benarbenar kering.

Air Filter, alat ini dipergunakan untuk menyaring debu yang terbawa oleh air.

Air Pressure Reducing Valve, berfungsi untuk mereduksi udara kempa pada batas yang dikehendaki dan menjaga agar tetap konstan pada saat digunakan.

Air Lubricator, alat ini berfungsi untuk mensuplai pelumas kedalam udara kempa dengan menggunakan aliran udara .

Air Silencer, berfungsi untuk mereduksi nozel yang timbul sampai pada batas yang aman.

Air Flow (Change Selenoide Valve), berfungsi untuk merubah (mengubah) aliran lkangsung dari kompresor dengan cara membuka atau menutup katup yang menerima singnal elektrik.

Speed Control Valve, berfungsi mengontrol kecepatan silinder dengan mengatur valve aliran dari udara kempa.

Air Cylinder, berfungsi untuk merubah energi udara kempa menjadi gaya yang efektif dan gerakan

\section{Kompresor}

Kompresor adalah mesin atau alat mekanik yang berfungsi untuk meningkatkan tekanan atau memampatkan fluida gas atau udara. Kompresor biasanya menggunakan motor listrik, mesin diesel atau mesin bensin sebagai tenaga penggeraknya. Udara bertekanan hasil dari kompresor biasanya diaplikasikan atau digunakan pada pengecatan dengan teknik spray/ air brush, untuk mengisi angin ban, pembersihan, pneumatik, gerinda udara (air gerinder) dan lain sebagainya.

\section{Solenoid Valve(Katub Arah)}

Solenoid valve merupakan sebuah komponen pneumatik yang bekerja berdasarkan input tegangan dan arus, yang mana saat solenoid valve ini bekerja tegangan yang diterima pada solenoidnya kurang lebih 24 volt dengan syarat tidak ada pembebanan dan arus yang diterima kurang lebih 0,2 ampere.

Solenoid yang dipergunakan dalam pembuatan alat ini adalah 5/2-Way single solenoid valve with $L E D$ dengan kosntruksi sebagai berikut :

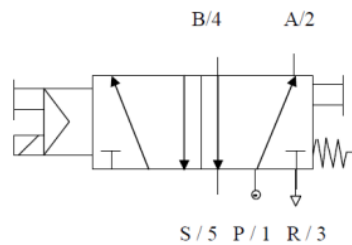

Gambar 4. 5/2-Way single solenoid valve

Solenoid jenis ini mempunyai bagian dalam yang terdiri dari lima saluran dan dua ruangan. Dalam solenoid valve ini terdapat dua output yang mana salah satu outputnya bekerja sebelum solenoidnya mendapat tegangan dan arus.

\section{Sensor Fiber Optik}

Sebuah sistem sensor serat optic terdiri dari kabel serat optic yang terhubung ke remote sensor atau penguat.

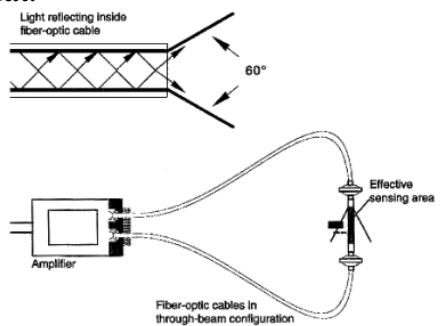

Gambar 5. Arsitektur Sensor Serat optic

Pada gambar diatas dalam penginderaan serat optic,Transmitter (Pengirim) dan Receiver (penerima) terletak dalam satu tempat. Kabel serat optic yang terhubung ke amplifier memungkinkan sensor untuk mencapai wilayah yang tidak terjangkau.

\section{Relay Magnetik Magnetik}

Relay magnetik merupakan piranti elektromagnetis yang berfungsi untuk memutuskan atau membuat kontak mekanik dan mempunyai kemampuan hantar arus yang lebih kecil.

\section{Light Emitting Diode (LED)}

Lampu LED atau kepanjangannya Light Emitting Diode adalah suatu lampu indikator dalam perangkat elektronika yang biasanya memiliki fungsi untuk menunjukkan status dari perangkat elektronika tersebut.

\section{Selector Switch}

Selector Switch terdiri dari poros yang dapat berputar satu atau lebih satu piringan yang menempelnya. Pada rangkaian kontrol sakelar pilih ini berfungsi sebagai sakelar utama dari sumber tegangan ke rangkaian kontrol.

\section{Sakelar Tekan}

Sakelar tekan (push button) merupakan perangkat/saklar sederhana yang berfungsi untuk menghubungkan atau memutuskan arus listrik dengan sistem kerja tekan unlock (tidak mengunci). 


\section{DIAGRAM ALUR}

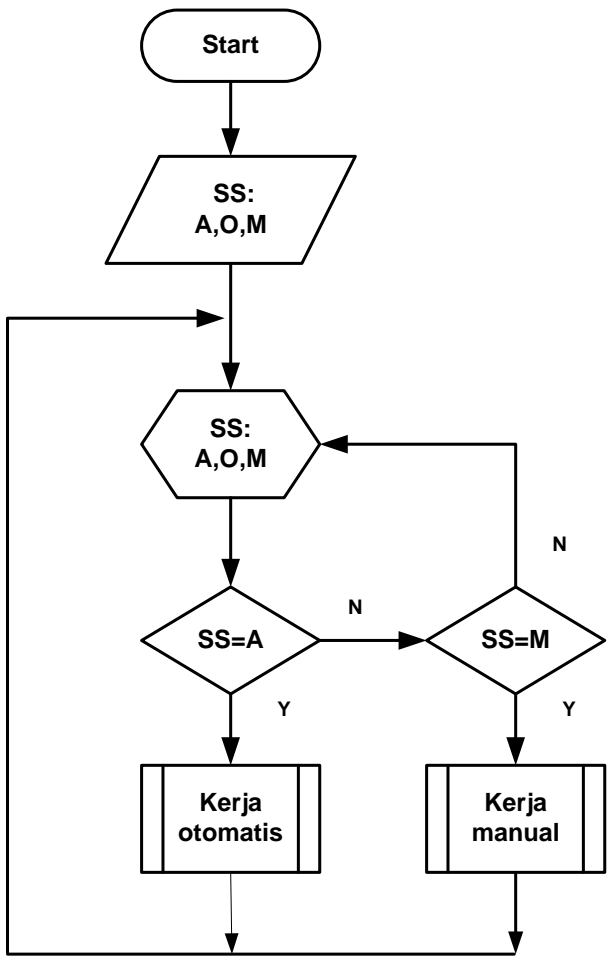

Gambar 6. Algoritma proses sortir secara global

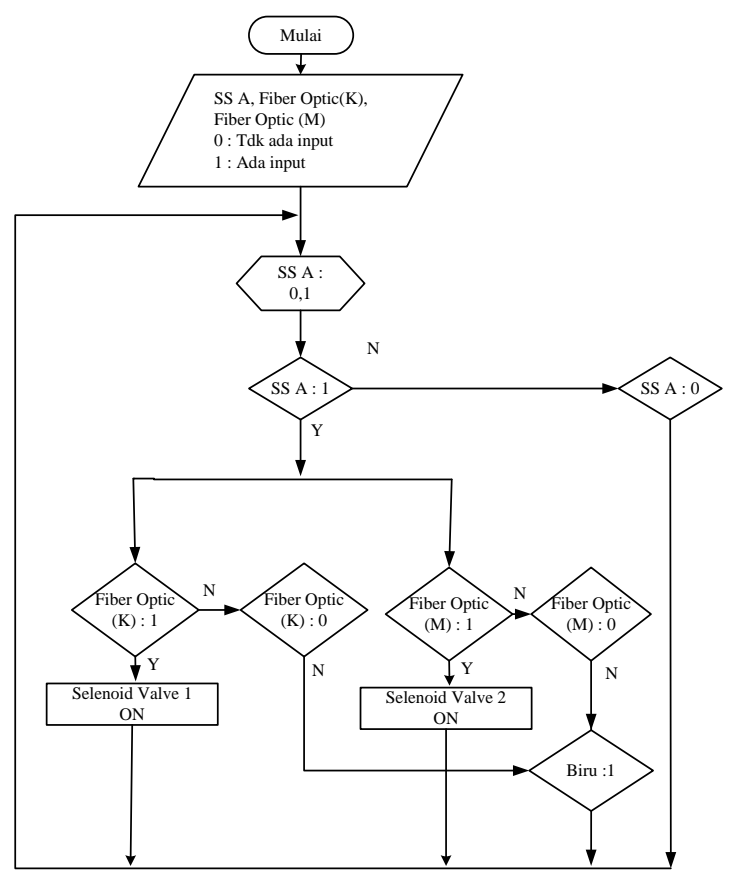

Gambar 7. Algoritma proses sortir secara Automatis

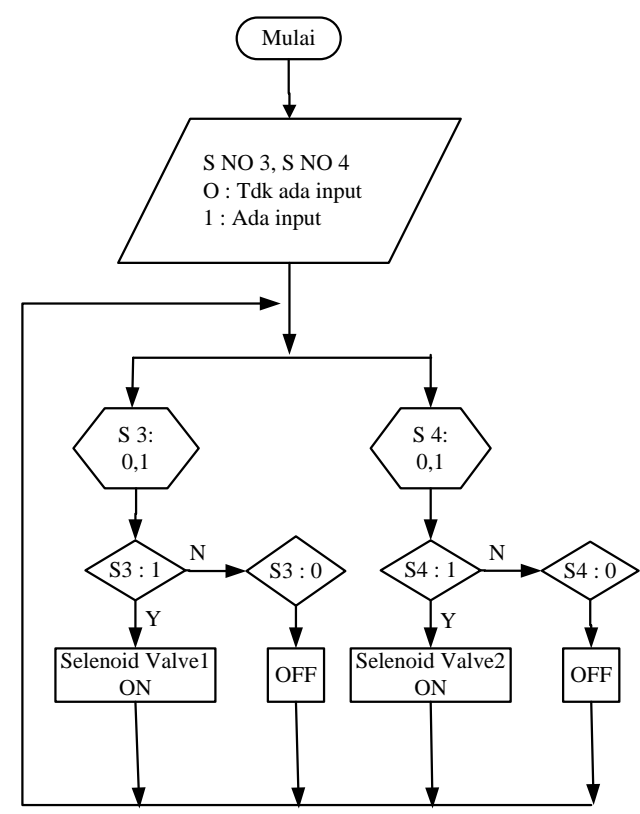

Gambar 8. Algoritma proses sortir secara Manual

\section{CARA KERJA SISTEM}

Dalam perancangan alat sortir warna bobbin benang ini dapat bekerja secara automatis maupun manual. Untuk menjalankan proses tersebut digunakan tombol push button dan selector switch yang berfungsi untuk menggerakkan bagian-bagian dari alat tersebut seperti motor konveyor dan solenoid valve untuk menggerakkan silinder. Sedangkan untuk pendeteksian benda kerja menggunakan sensor photodioda dan untuk proses sortir warna bobbin benang menggunakan sensor fiber optic.

Pada posisi automatic setelah bobbin benang terbawa konveyor terdapat sensor fiber optic yang akan menentukan warna bobbin tersebut. Dalam perancangan alat ini digunakan 2 ( dua ) sensor fiber optic . Fiber optic 1 untuk mendeteksi warna Kuning, apabila terdeteksi terdapat bobbin benang berwarna kuning maka sensor akan mengirimkan sinyal ke PLC untuk mengaktifkan solenoid valve 1 dan menggerakan Silinder 1 . Silinder 1 akan mendorong bobbin sampai ke penampung bobbin kuning, kemudian bobbin kuning mengenai sensor Photo Diode 2 yang berfungsi untuk mematikan Silinder 1. Fiber optic 2 untuk mendeteksi warna Merah, apabila terdeteksi terdapat bobbin benang berwarna Merah maka sensor akan mengirimkan sinyal ke PLC untuk mengaktifkan selenoid valve 2 dan menggerakan Silinder 2. Silinder 2 akan mendorong bobbin benang sampai ke penamapung bobbin Merah, kemudian bobbin merah mengenai sensor Photo Diode 3 yang berfungsi untuk mematikan Silinder 2. Apabila benang tersebut tidak terdeteksi oleh kedua sensor fiber optic berarti bobbin benang tersebut berwarna Biru, maka bobin benang tersebut akan diteruskan konveyor melintas sampai ke tandon bobbin Biru. 
Pada posisi manual, dapat dioperasikan sesuai dengan yang diinginkan atau secara tidak berurutan, yaitu dengan cara menekan button (A) untuk mengaktifkan Solenoid Valve 1 dan mendorong Silinder 1, Button (B) untuk mengaktifkan Solenoid Valve 2 dan mendorong Silinder 2.

\section{PEMBUATAN SISTEM}

Pembuatan Perangkat keras ( Hardware )

Pemasangan perangkat keras ini bertujuan untuk menunjang software CX-Supervisor dalam menjalankan fungsi monitor dan control sistem.

Tabel 1. Perangkat Keras Yang Digunakan Beserta Fungsinya

\begin{tabular}{|c|c|c|c|}
\hline No & Nama Barang & Jumlah & Fungsi \\
\hline 1 & $\begin{array}{l}\text { PLC CP1E-N } \\
\text { 30DRA }\end{array}$ & 1 Buah & $\begin{array}{l}\text { Sebagai Penghubung Input } \\
\text { dan Output yang digunakan }\end{array}$ \\
\hline 2 & Amplifier BF4R & 2 Buah & $\begin{array}{l}\text { Sebagai pendeteksi warna } \\
\text { pada bobbin benang }\end{array}$ \\
\hline 3 & Kabel Serat Optik & 2 Buah & $\begin{array}{l}\text { Media Penghubung antara } \\
\text { sensor dengan Amplifier }\end{array}$ \\
\hline 4 & Kompressor & 1 Buah & $\begin{array}{ll}\text { Pensuplai } & \text { Udara } \\
\text { Bertekanan } & \end{array}$ \\
\hline 5 & Air Regulator & 1 Buah & $\begin{array}{l}\text { Mengontrol tekanan udara } \\
\text { yang dibutuhkan sebelum } \\
\text { masuk ke pneumatic }\end{array}$ \\
\hline 6 & Solenoid Valve & 2 Buah & $\begin{array}{l}\text { Mengontrol Arah Keluar } \\
\text { dan Masuknya Udara }\end{array}$ \\
\hline 7 & $\begin{array}{l}\text { Silinder Pneumatik } \\
\text { (Aktuator) }\end{array}$ & 2 Buah & $\begin{array}{l}\text { Mendorong bobbin ke } \\
\text { penampungan benang } \\
\text { sesuai dengan wama }\end{array}$ \\
\hline 8 & Selang Udara & 2 Meter & $\begin{array}{l}\text { Sebagai Media pembawa } \\
\text { udara bertekanan }\end{array}$ \\
\hline 9 & Speed Control & 2 Buah & \begin{tabular}{lr} 
Pengatur & \multicolumn{2}{r}{ Kecepatan } \\
Silinder pada saat \\
mendorong
\end{tabular} \\
\hline 10 & Salancer & 4 Buah & Peredam Udara Kelur \\
\hline 11 & Fitting Pneumatik & 10Buah & $\begin{array}{l}\text { Penghubung Selang udara } \\
\text { dengan peralatan pneumatic }\end{array}$ \\
\hline 12 & MCB 1 Phasa & 1 Buah & $\begin{array}{l}\text { Pengaman PLC } \\
\text { Menghubungkan Kontak }\end{array}$ \\
\hline 13 & Relay Magnetik & 4 Buah & $\begin{array}{l}\text { Output PLC dengan } \\
\text { Peralatan }\end{array}$ \\
\hline 14 & Lampu Pilot & 2 Buah & $\begin{array}{l}\text { Indikator } \\
\text { Peralatan }\end{array}$ \\
\hline
\end{tabular}

\section{Pembuatan Rangka Alat Sortir}

Pembuatan rangka alat sortir ini menggunakan besi dengan tujuan untuk dapat dibebani dengan peralatan yang berat

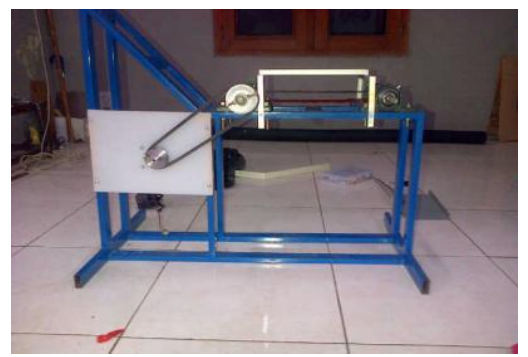

Gambar 9. Hardware Rangka Alat Sortir

\section{Pembuatan Papan Blok Peralatan}

Pembuatan Blok peralatan ini berfungsi sebagai tempat penempelan komponen seperti : PLC, Selenoid Valve, MCB, Air Regulator, Amplifier BF4R, Relay Magnetik, Driver Sensor. Papan blog peralatan dibuat dengan bahan Akrilik dengan tebal $0,5 \mathrm{~cm}$.

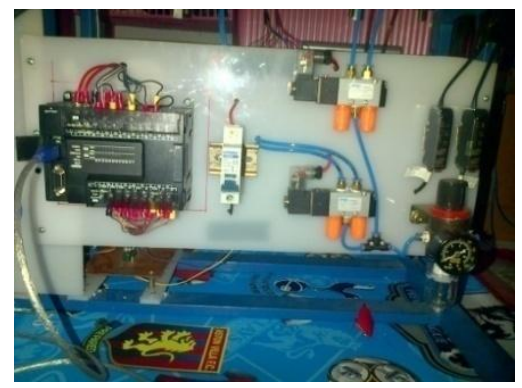

Gambar 10. Papan Blok yang telah ditempel dengan peralatan

\section{Mengatur Penempatan Posisi Silinder Pneumatik}

Penemapatan Posisi Silinder 1 dan Silinder 2 yaitu di samping belt konvenyor. Silinder pertama digunakan untuk mendorong bobbin berwarna kuning dan silinder 2 digunakan untuk mendorong bobbin berwarna merah.

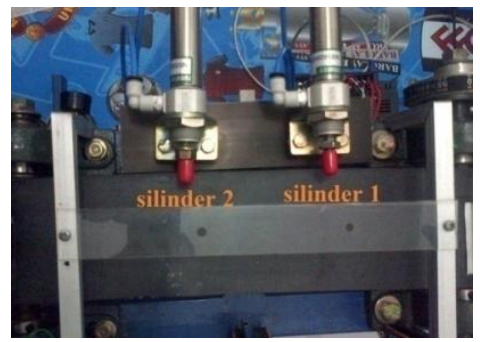

Gambar 11. Penempatan Silinder 1 dan Silinder 2 pada alat sortir warna bobbin benang

\section{Pengaturan Posisi Sensor Fiber Optik}

Penempatan posisi sensor fiber optic yaitu di atas belt konveyor yang sebeumnya telah terpasang media penempelan dan penyangga yang terbuat dari akrilik dengan tebal $20 \mathrm{~mm}$ sebagai media penempelan sensor dan alumunium sebagai tiang penyangganya. 


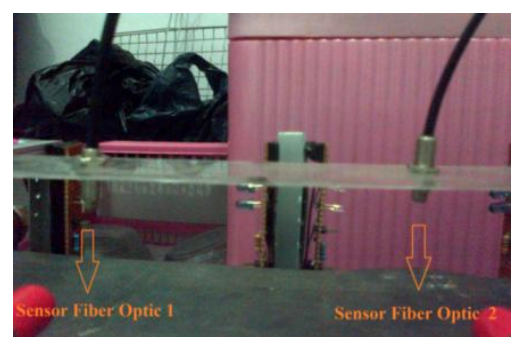

Gambar 12. Penempatan Posisi Sensor Fiber Optic

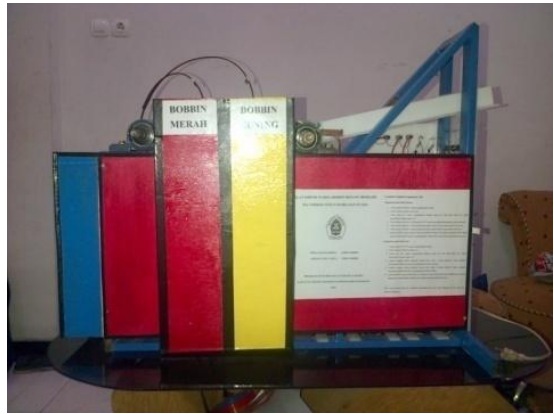

Gambar 13. Tampilan Hardware Tampak Depan

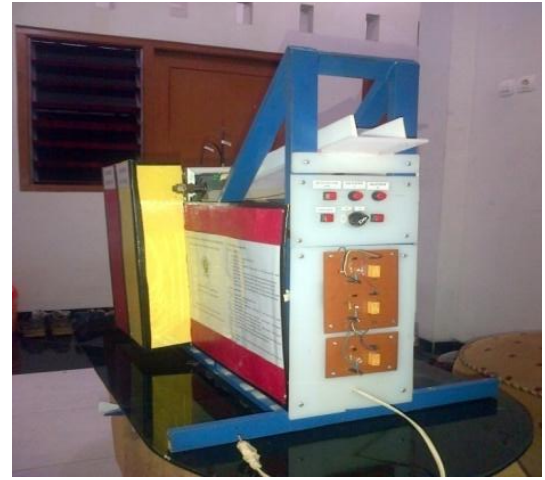

Gambar 14. Tampilan Harware Tampak Samping Kanan

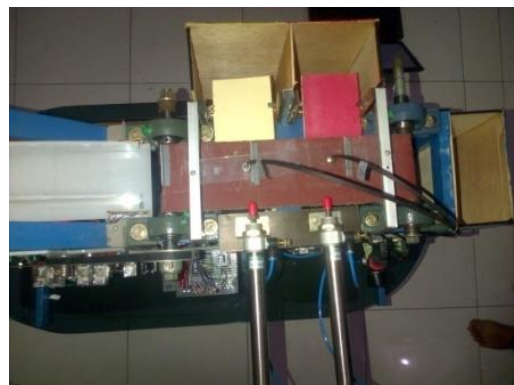

Gambar 15. Tampilan Harware Tampak Atas

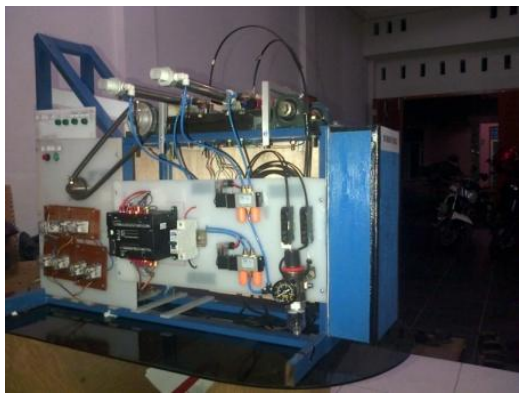

Gambar 16. Tampilan Hardware Tampak Belakang

\section{Pembuatan Perangkat Lunak (Software)}

Dalam tugas akhir ini pembuatan perangkat lunak terbagi menjadi 2 bagian,yaitu : Pembuatan Ladder Diagram untuk pengalamatan Input Output yang dibutuhkan oleh PLC dan pembuatan animasi SCADA.

Gambar 17 adalah gambar diagram ladder dari sistem yang dibuat. Sedangkan deretan instruksi mnemonic ditunjukkan pada tabel 2 .

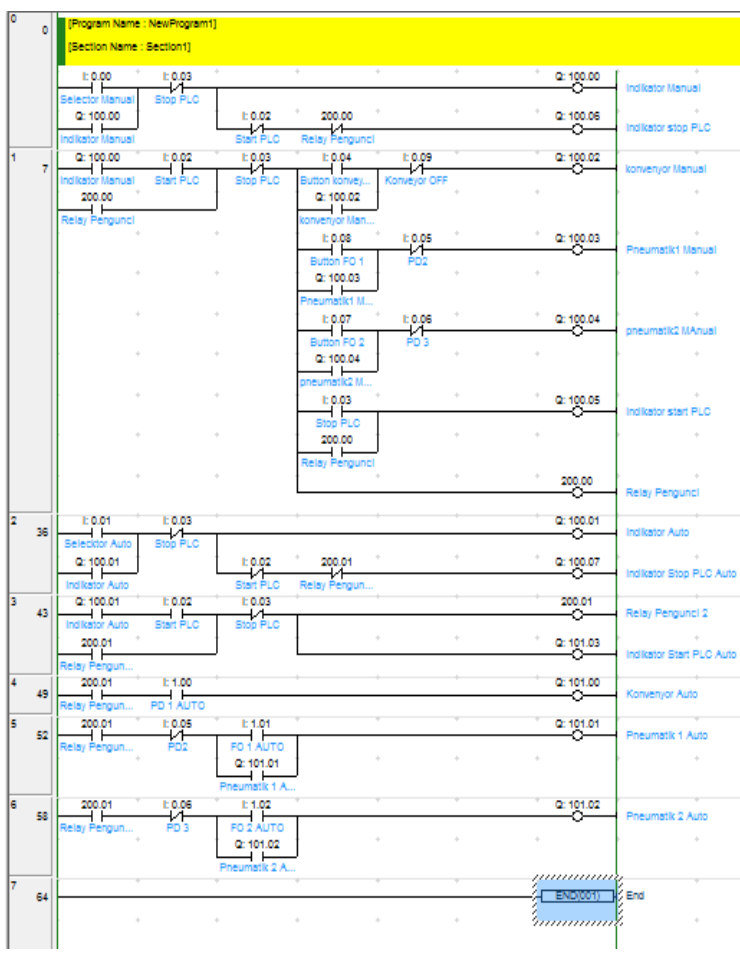

Gambar 17. Diagram Ladder Sistem Keseluruhan

Berikut ini tampilan seluruh pages tiap peralatan nya telah dihubungkan satu dengan yang lainnya.

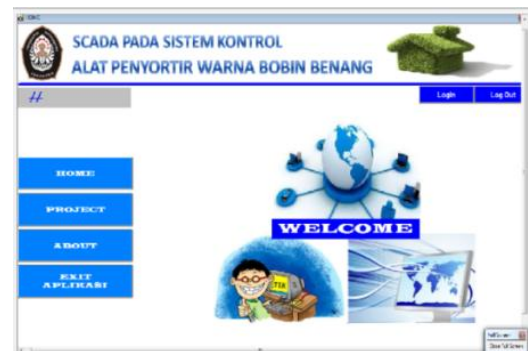

Gambar 18. Tampilan Final SCADA Page "Мепи"

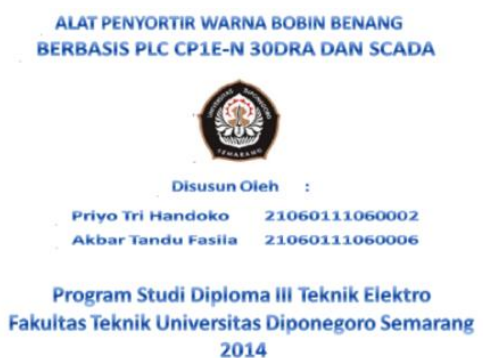
2014

Gambar 19. Tampilan Final SCADA page "Home" 
Tabel 2. Mneumonik Sistem Keseluruhan

\begin{tabular}{|c|c|c|c|}
\hline $\begin{array}{c}\text { Step } \\
0\end{array}$ & $\begin{array}{c}\text { Instruksi } \\
\text { LD }\end{array}$ & $\begin{array}{l}\text { Operand } \\
\text { I } 0.00\end{array}$ & $\begin{array}{c}\text { Keterangan } \\
\text { Selector Manual }\end{array}$ \\
\hline 1 & OR & Q:100.00 & Indikator Mannual \\
\hline 2 & ANDNOT & I0.03 & Stop PLC \\
\hline 3 & OUT & Q: $100 . \infty$ & Indikator Mamual \\
\hline 4 & AND NOT & $\mathrm{I} 0.02$ & Start PLC \\
\hline 5 & ANDNOT & 200.00 & Relay Pengunci \\
\hline 6 & OUT & Q:100.06 & Indikator Stop PLC \\
\hline 7 & LD & Q:100.ळ & Indikator Marual \\
\hline 8 & AND & $\mathrm{I} ; 0.02$ & Start PLC \\
\hline 9 & OR & 200.00 & Relay Pengunci 1 \\
\hline 10 & ANDLD & $\mathrm{I}: 0.03$ & Stop PLC \\
\hline 11 & OUT & TR0 & \\
\hline 12 & LD & I.0.04 & Button Konveyor ON \\
\hline 13 & $\overline{\mathrm{OR}}$ & Q:100.02 & Konveyor Manual \\
\hline 14 & ANDLD & & \\
\hline 15 & ANDNOT & $\mathrm{I} 0.09$ & Button Konveyor OFF \\
\hline 16 & OUT & Q:100.02 & Konveyor Manual \\
\hline 17 & LD & TR0 & \\
\hline 18 & LD & $\mathrm{I} 0.08$ & Button Silinder 1 \\
\hline 19 & $\overline{\mathrm{OR}}$ & Q:100.03 & Pneumatik 1 Manual \\
\hline 20 & ANDLD & & \\
\hline 21 & ANDNOT & I 0.05 & Photodiode 2 \\
\hline 22 & OUT & Q:100.03 & Pneumatik 1 Manual \\
\hline 23 & LD & TR0 & \\
\hline 24 & LD & $\mathrm{I} 0.07$ & Button Silinder 2 \\
\hline 25 & OR & $\mathrm{Q}: 100.3$ & Pneumatik 2 Manual \\
\hline 26 & ANDLD & & \\
\hline 27 & ANDNOT & $\mathrm{I} 0.06$ & Photodiode 3 \\
\hline 28 & OUT & 200.00 & Pneumatik 2 Manual \\
\hline 29 & LD & TR0 & \\
\hline 30 & LD & $\mathrm{I} 0.03$ & Stop PLC \\
\hline 31 & OR & 200.00 & Relay Pengunci 1 \\
\hline 32 & ANDNOT & & \\
\hline
\end{tabular}

\begin{tabular}{|c|c|c|c|}
\hline Step & Instruksi & Operand & Keterangan \\
\hline 33 & OUT & Q100.05 & Indikator Start PLC \\
\hline 34 & LD & TR0 & \\
\hline 35 & OUT & 200.00 & Relay Pengunci 1 \\
\hline 36 & LD & $\mathrm{I} 0.01$ & Selector Auto \\
\hline 37 & OR & Q:100.01 & Indikator Auto \\
\hline 38 & ANDNOT & I003 & Stop PLC \\
\hline 39 & OUT & Q:100.01 & Indikator Auto \\
\hline 40 & ANDNOT & $\mathrm{I} 0.02$ & Start PLC \\
\hline 41 & ANDNOT & 200.01 & Relay Pengunci 2 \\
\hline 42 & OUT & Q:100.07 & Indikator Stop PLC Auto \\
\hline 43 & LD & Q:100.01 & Indikator Auto \\
\hline 44 & AND & I0.02 & Start PLC \\
\hline 45 & $\mathrm{OR}$ & 200.01 & Relay Pengunci 2 \\
\hline 46 & ANDNOT & $\mathrm{I} 0.03$ & Stop PLC \\
\hline 47 & OUT & 200.01 & Relay Pengunci 2 \\
\hline 48 & OUT & Q:101.03 & Indikator Start PLC Auto \\
\hline 49 & LD & 20001 & Relay pengunci 2 \\
\hline 50 & AND & $\mathrm{I} 1.00$ & Photodiode 1 \\
\hline 51 & OUT & Q:101.00 & Konvenyor Auto \\
\hline 52 & LD & 20001 & Relay Pengunci 2 \\
\hline 53 & ANDNOT & I.0.05 & Photodiode 2 \\
\hline 54 & AND & $\mathrm{I} 1.00$ & Sensor Fiber Optic 1 \\
\hline 55 & OUT & Q:101.00 & Pneumatik 1 Auto \\
\hline 56 & LD & 200.01 & Relay pengunci 2 \\
\hline 57 & ANDNOT & I 106 & Photodiode 3 \\
\hline 58 & AND & I-1.02 & Sensor Fiber Optik 2 \\
\hline 59 & OUT & $\mathrm{Q}: 101.02$ & Pneumatik 2 Auto \\
\hline
\end{tabular}

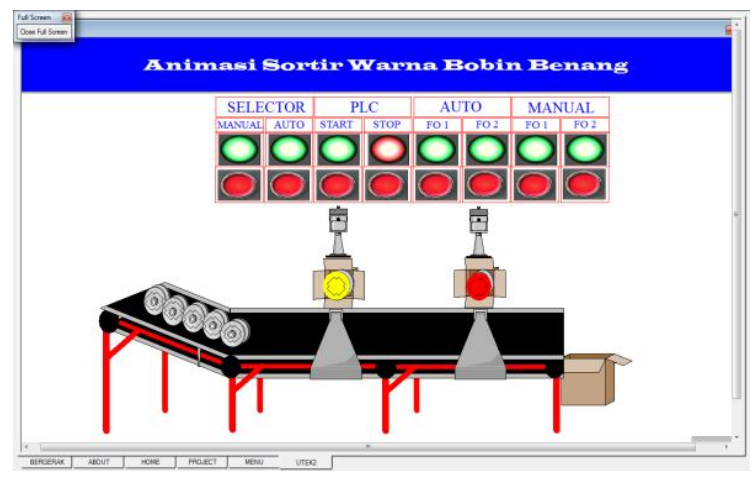

Gambar 20. Tampilan Final SCADA page "Project" 
SCADA (SUPERVISORY CONTROLAND DATA AQUISITION)

VERSION 1.0

Copyright @2014 Priyo Tri H \& Akbar Tandu

PSD III TEKNIK ELEKTRO FAKULTAS TEKNIK UNIVERSITAS DIPONEGORO ок

Gambar 21. Tampilan final SCADA Page "About"

\section{PENGUJIAN SCADA DAN PENGUKURAN}

ALAT

Pengukuran Input-Output PLC CP1E N30DR-A

Langkah pengukuran Input-Output PLC

CPIE-N30 DR-A adalah sebagai berikut:

- Menghubungkan catu daya $220 \mathrm{~V}_{\mathrm{AC}}$ pada terminal unit catu daya $P L C$.

- Menghubungkan terminal input PLC dengan koponen input sistem dan menghubungkan terminal output PLC dengan komponen output sistem.

- Membuat program ladder diagram yang dapat memberikan sinyal pada keseluruhan terminal input-output.

- Mengukur tegangan yang terjadi pada terminal input saat mendapat masukan dari komponen input luar.

- Mengukur tegangan output yang muncul pada terminal PLC akibat adanya input pada terminal PLC

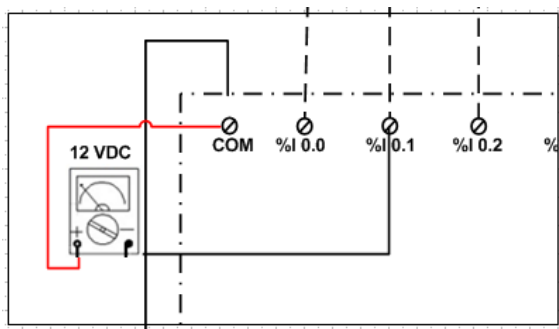

Gambar 22. Titik Pengukuran Input PLC

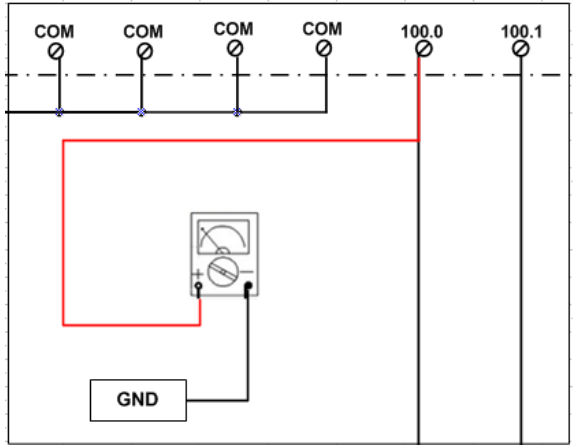

Gambar 23. Titik Pengukuran Output PLC

Hasil Pengukuran Rangkaian Input dan Output pada PLC Omron CP1E-N30DR-A dalam kondisi Manual dan Otomatis dapat dilihat pada tabel 3 dan 4
Tabel 3. Pengukuran saat saklar pilih dalam kondisi manual

\begin{tabular}{|c|c|c|c|}
\hline No. & Selector Manual & $\begin{array}{c}\text { Kodisi } \\
\text { ( ON / OFF ) } \\
\text { ON } \\
\text { OFF }\end{array}$ & $\begin{array}{c}\text { Tegangan } \\
\text { ( Volt DC ) } \\
12,18 \mathrm{~V}_{\mathrm{DC}} \\
0 \mathrm{~V}_{\mathrm{DC}}\end{array}$ \\
\hline \multirow{2}{*}{2.} & \multirow{2}{*}{ Indikator Manual } & ON & $12,18 \mathrm{~V}_{\mathrm{DC}}$ \\
\hline & & OFF & $0 V_{D C}$ \\
\hline \multirow{2}{*}{3.} & \multirow{2}{*}{ Start PLC } & ON & $12,18 \mathrm{~V}_{\mathrm{DC}}$ \\
\hline & & OFF & $0 \mathrm{~V}_{\mathrm{DC}}$ \\
\hline \multirow{2}{*}{4.} & Indikator Start PLC & ON & $12,18 V_{D C}$ \\
\hline & Manual & OFF & $0 \mathrm{~V}_{D C}$ \\
\hline 5. & Stop PLC & $\begin{array}{l}\text { ON } \\
\text { OFF }\end{array}$ & $\begin{array}{c}12,18 \mathrm{~V}_{\mathrm{DC}} \\
0 \mathrm{~V}_{\mathrm{DC}}\end{array}$ \\
\hline \multirow{2}{*}{6.} & \multirow{2}{*}{$\begin{array}{c}\text { Indikator Stop PLC } \\
\text { Manual }\end{array}$} & ON & $12,18 V_{D C}$ \\
\hline & & OFF & $0,1 V_{D C}$ \\
\hline \multirow[t]{2}{*}{5.} & \multirow[t]{2}{*}{ Button Valve 1} & ON & $12,18 \mathrm{~V}_{\mathrm{DC}}$ \\
\hline & & OFF & $0 V_{D C}$ \\
\hline \multirow[t]{2}{*}{6.} & \multirow[t]{2}{*}{ Indikator Valve 1 Mamual } & ON & $12,18 \mathrm{~V}_{\mathrm{DC}}$ \\
\hline & & OFF & $0 \mathrm{~V}_{\mathrm{DC}}$ \\
\hline \multirow[t]{2}{*}{7.} & \multirow[t]{2}{*}{ Button Valve 2} & ON & $12,18 \mathrm{~V}_{\mathrm{DC}}$ \\
\hline & & OFF & $0 \mathrm{~V}_{D C}$ \\
\hline & \multirow[t]{2}{*}{ Indikator Valve 2 Manual } & ON & $12,18 \mathrm{~V}_{\mathrm{DC}}$ \\
\hline & & OFF & $0 V_{D C}$ \\
\hline
\end{tabular}

Tabel 4. Pengukuran saat saklar pilih dalam kondisi otomatis

\begin{tabular}{|c|c|c|c|}
\hline No. & Keterangan & $\begin{array}{c}\text { Kodisi } \\
\text { (ON / OFF ) }\end{array}$ & $\begin{array}{l}\text { Tegangan } \\
\text { (Volt DC) }\end{array}$ \\
\hline \multirow{2}{*}{1.} & \multirow{2}{*}{ Selector Auto } & ON & $12,18 \mathrm{~V}_{\mathrm{DC}}$ \\
\hline & & OFF & $0 \mathrm{~V}_{\mathrm{DC}}$ \\
\hline \multirow{2}{*}{2.} & \multirow{2}{*}{ Indikator Auto } & ON & $12,18 \mathrm{~V}_{\mathrm{DC}}$ \\
\hline & & OFF & $0 V_{D C}$ \\
\hline \multirow{2}{*}{3.} & \multirow{2}{*}{ Start PLC } & ON & $12,18 \mathrm{VDC}$ \\
\hline & & OFF & $0 \mathrm{~V}_{D C}$ \\
\hline \multirow{2}{*}{4.} & \multirow{2}{*}{ Indikator Start PLC Auto } & ON & $12,18 V_{D C}$ \\
\hline & & OFF & $0 V_{D C}$ \\
\hline \multirow{2}{*}{5.} & \multirow{2}{*}{ Stop PLC } & ON & $12,18 \mathrm{~V}_{\mathrm{DC}}$ \\
\hline & & OFF & $0 \mathrm{~V}_{\mathrm{DC}}$ \\
\hline & \multirow{2}{*}{ Indikator Stop PLC Auto } & ON & $12,18 \mathrm{~V}_{\mathrm{DC}}$ \\
\hline & & OFF & $0 \mathrm{~V}_{\mathrm{DC}}$ \\
\hline \multirow[t]{2}{*}{5.} & \multirow[t]{2}{*}{ Sensor Fiber Optik 1} & ON & $12,18 \mathrm{~V}_{\mathrm{DC}}$ \\
\hline & & OFF & $0 \mathrm{~V}_{\mathrm{DC}}$ \\
\hline \multirow[t]{2}{*}{6.} & \multirow[t]{2}{*}{ Indikator Valve 1 Auto } & ON & $12,18 \mathrm{~V}_{\mathrm{DC}}$ \\
\hline & & OFF & $0 \mathrm{~V}_{\mathrm{DC}}$ \\
\hline & \multirow[t]{2}{*}{ Sensor Fiber Optik 2} & ON & $12,18 \mathrm{~V}_{\mathrm{DC}}$ \\
\hline & & OFF & $0 V_{D C}$ \\
\hline & \multirow[t]{2}{*}{ Indikator Valve 2 Auto } & ON & $12,18 V_{D C}$ \\
\hline & & OFF & $0 \mathrm{~V}_{\mathrm{DC}}$ \\
\hline
\end{tabular}

\section{Pengukuran sensor Fiber Optik}

Langkah pengukuran rangkaian Sensor Fiber Optic adalah sebagai berikut:

- Menghubungkan multimeter ke rangkaian penerima sensor cahaya dengan sumber tegangan $12 \mathrm{~V}_{\mathrm{DC}}$.

- Menghidupkan rangkaian sensor dan menaruh bobbin berwarna pada target pensensoran dan mematikan aplikasi lain.

- Mengukur tegangan keluaran dari rangkaian penerima sensor saat mendeteksi warna dan saat tidak mendeteksi warna. 


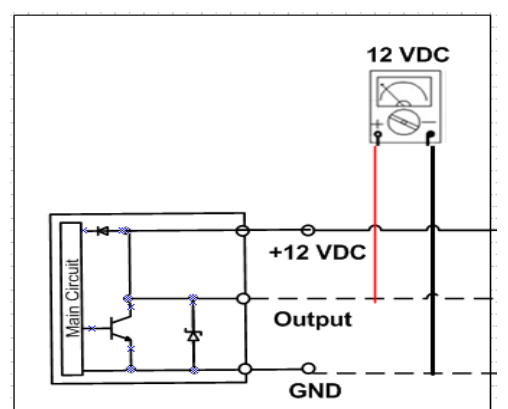

Gambar 24. Titik Pengukuran Output Sensor Fiber optic

Tabel 5. Hasil Pengukuran Output Sensor Fiber Optik

\begin{tabular}{|ccc|}
\hline Aplikasi & Kond isi & T egangan $\left(V_{\text {DC }}\right)$ \\
\hline Sensor Fiber & Mendetelsi Bobbin & 0 \\
Optic 1 & warna Kuning & Tidak Mendetelcsi \\
Sensor Fiber & Mendetelsi Bobbin & 12 \\
Optic 2 & wama Merah & 0 \\
Tidak Mendetelcsi & 12 \\
\hline
\end{tabular}

\section{Pengukuran tegangan pada Solenoid Valve}

Langkah pengukuran pada Solenoid Valve adalah sebagai berikut:

- Menghubungkan rangkaian catu daya 220 VAC dengan Solenoid Valve.

- Menghidupkan Solenoid Valve dengan cara menekan Button Silinder pada panel kontrol .

- Mengukur tegangan pada Selenoid Valve pada saat On/Off.

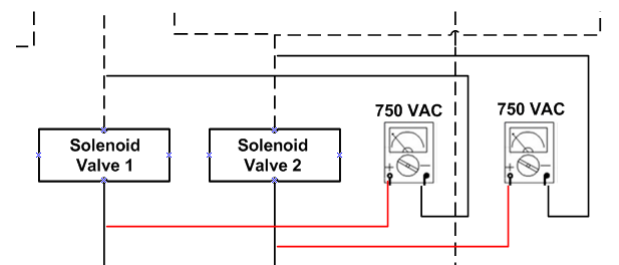

Gambar 25. Titik Pengukuran Solenoid Valve

Tabel 6. Hasil Pengukuran Solenoid Valve

\begin{tabular}{|ccc|}
\hline Aplikasi & Kondisi & T egangan $\left(\mathrm{V}_{\boldsymbol{A C}}\right)$ \\
\hline \multirow{2}{*}{ Solenoid Valve } & Bekerja & 225 \\
& Tidak Bekeja & 0 \\
\hline
\end{tabular}

\section{Pengujian Program PLC dengan Cx-Programer}

Pengujian ini dilakukan untuk memeriksa program yang telah tersimpan dalam memori PLC sudah sesuai dengan Input-Output sistem, agar pada saat berlangsungnya sistem tidak terjadi kesalahan dalam pengalamatan Input-Output pada PLC.Langkah-langkah pengujian sebagai berikut.

\section{Pada Kondisi Manual}

Langkah-Langkah pengujian sortir warna dengan sistem manual adalah sebagai berikut :

- Memberikan logika "1"(High) pada input Selector Manual (0.00)

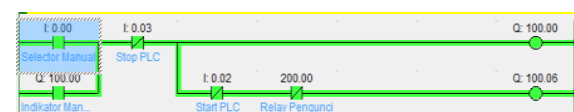

Gambar 26. Tampilan Ladder Sistem Manual Saat Berjalan

- Memberikan logika “1”(High) pada input Start PLC (0.02)

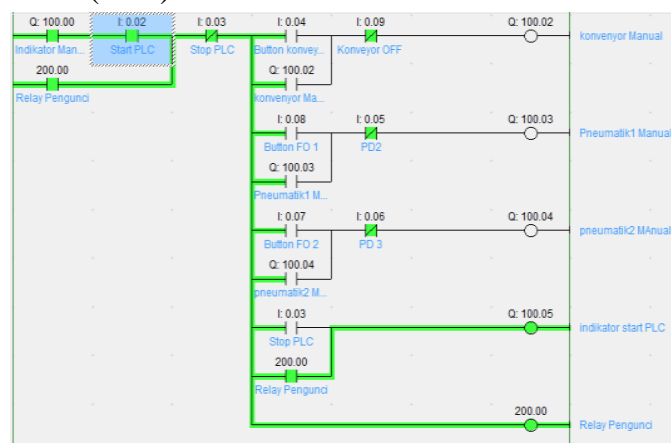

Gambar 27. Tampilan Ladder Saat Start PLC Manual "HIGH"

- Untuk mengaktifkan Pneumatik 1 maka pada input Silinder 1 Manual (0.08) diberikan logika "1"(High).

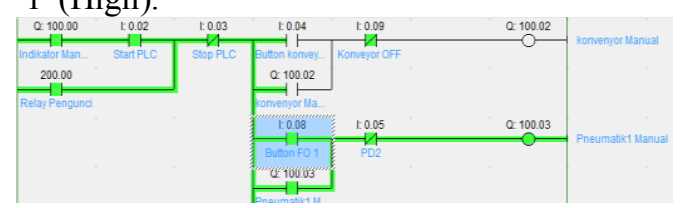

Gambar 28 Tampilan Ladder Saat Button Valve "HIGH"

- 4.Untuk mengaktifkan Pneumatik 2 maka pada input Silinder 2 Manual (0.07) diberikan logika "1"(High).

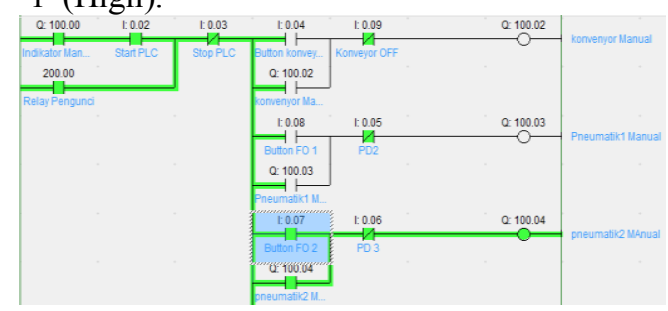

Gambar 29. Tampilan Ladder Saat Button Valve 2 "HIGH"

Pada Sistem Auto

Langkah-Langkah pengujian sortir warna dengan sistem Auto adalah sebagai berikut :

- Memberikan logika "1" (High) pada input

Selector Auto (0.01)

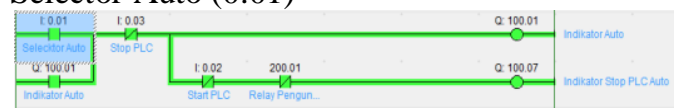

Gambar 30. Tampilan Ladder Sistem Auto Saat Berjalan

- Memberikan logika "1"(High) pada input Start PLC (0.02) 


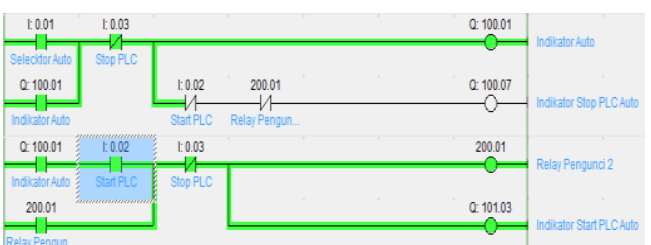

Gambar 31. Tampilan Ladder Saat Start PLC Manual "HIGH"

- Untuk mengaktifkan Pneumatik 1 maka diperlukan bobbin warna kuning sebagai objek pensensoran Fiber Optik 1 yang mengirimkan sinyal (High) ke terminal input (1.01) PLC

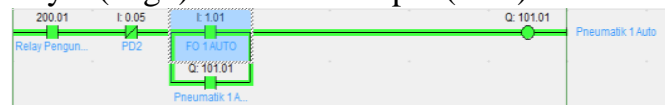

Gambar 32. Tampilan Ladder Saat Fiber Optik 1 " $H I G H$ "

- Untuk mengaktifkan Pneumatik 2 maka diperlukan bobbin warna merah sebagai objek pensensoran Fiber Optik 2 yang akan mengirimkan sinyal (High) ke terminal input (1.02) PLC

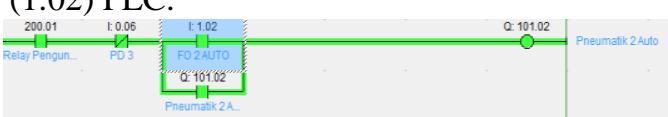

Gambar 33. Tampilan Ladder Saat Fiber Optik 2 "HIGH"

\section{Pengujian SCADA dengan Cx-Supervisor Secara Manual}

Pada pengujian secara Manual langkah pertama yang harus dilakukan adalah mengklik tombol Manual yang ada pada layar simulasi kemudian indikator Manual akan menyala

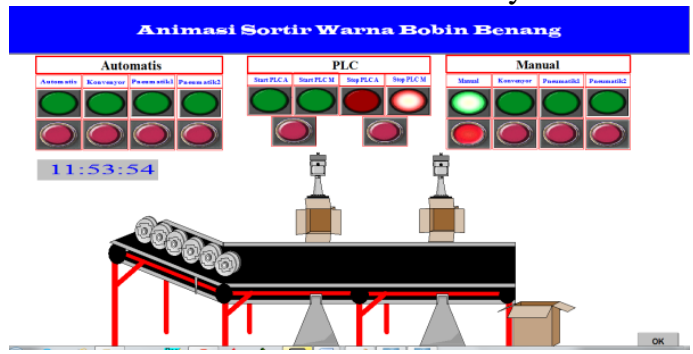

Gambar 34 Tampilan Operasi Manual

Langkah Kedua yaitu dengan meng-klik tombol Start PLC yang ada pada layar simulasi sebagai tanda Start Sistem Manual kemudian inidkator Start PLC akan menyala seperti gambar 35 .

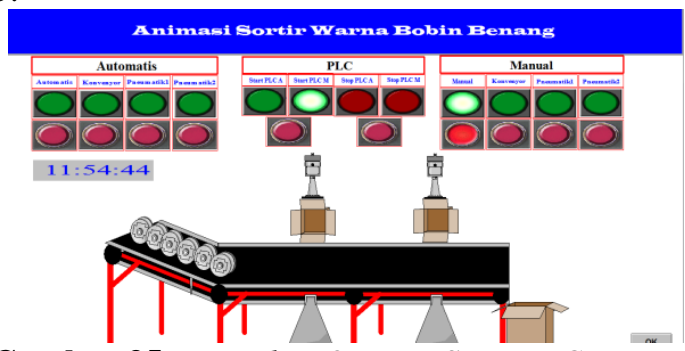

Gambar 35. Tampilan Operasi Start PLC Manual
Setelah bobbin warna kuning terbawa konveyor sampai berada tepat dibawah sensor Fiber Optic 1 maka dengan menekan tombol Pneumatik 1 Manual,akan menggerakkan silinder 1 dan menghidupkan Indikator

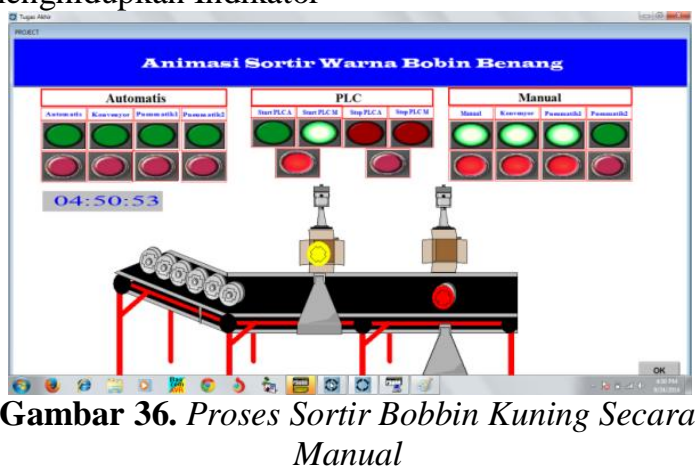

Setelah bobbin warna merah terbawa konveyor dampai berada tepat dibawah sensor Fiber Optic 2 maka dengan menekan tombol Pneumatik 2 Manual,akan menggerakkan silinder 2 dan menghidupkan Indikator Pada Pneumatik 2 Manual

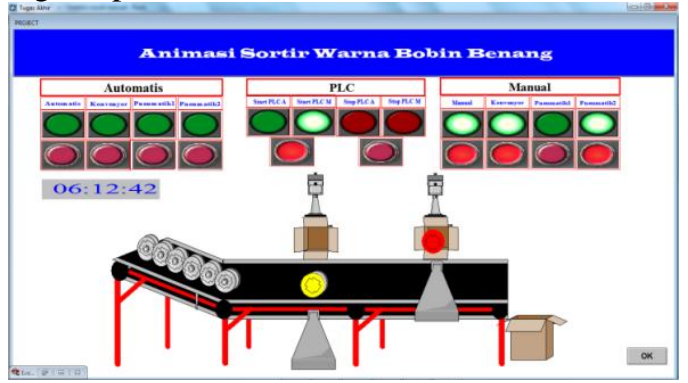

Gambar 37. Proses Sortir Bobbin Kuning Secara Manual

Bobin terbawa konveyor sampai menuju ke penambungan warna biru tanpa terdeksi oleh kedua sensor Fiber optic seperti pada gambar 5.17 berikut.

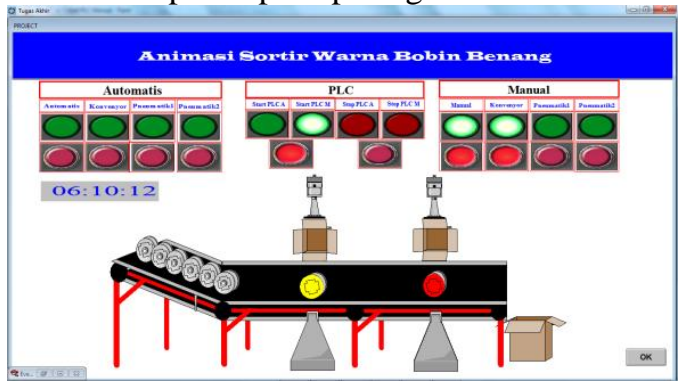

Gambar 38. Proses Awal Sortir Bobbin Biru Secara Manual

\section{Secara Otomatis}

Pada pengujian secara otomatis, langkah pertama yang harus dilakukan adalah mengklik tombol Auto yang ada pada layar simulasi kemudian indikator Auto akan menyala. 


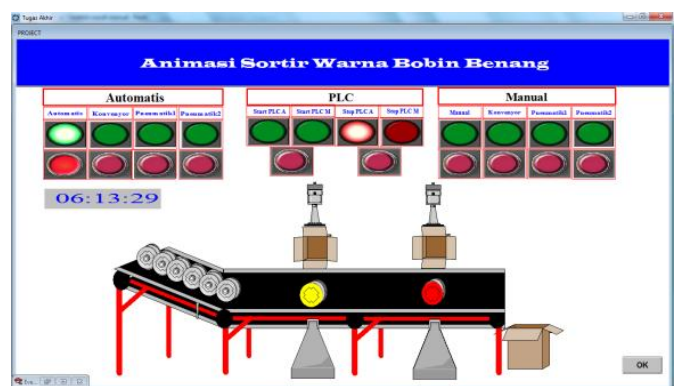

Gambar 39. Tampilan Operasi Auto

Langkah Kedua yaitu dengan meng-klik tombol Start PLC yang ada pada layar simulasi sebagai tanda Start Sistem Auto kemudian inidkator Start PLC Auto akan menyala.

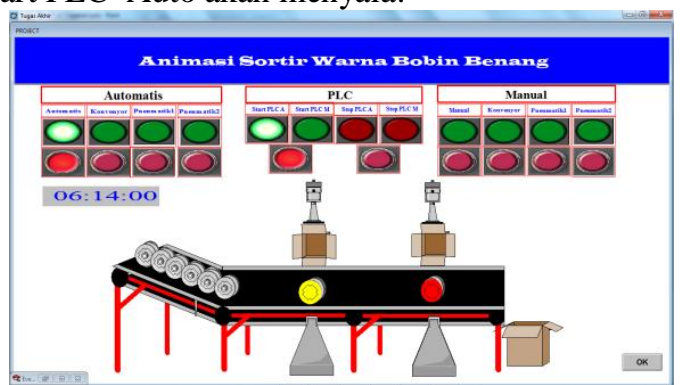

Gambar 40. Tampilan Operasi Start PLC Auto

Setelah bobbin warna kuning terbawa konveyor dampai berada tepat dibawah sensor Fiber Optic 1 maka silinder 1 akan mendorong secara otomatis dan menghidupkan Indikator Pada Pneumatik 1 Auto.

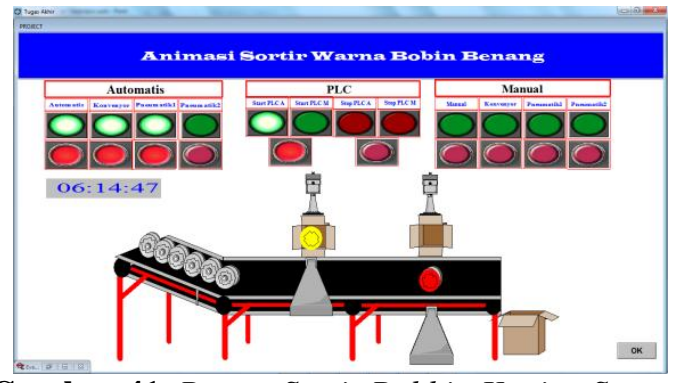

Gambar 41. Proses Sortir Bobbin Kuning Secara Manual

Setelah bobbin warna merah terbawa konveyor sampai berada tepat dibawah sensor Fiber Optic 2 maka silinder 2 akan mendorong secara otomatis dan menghidupkan Indikator Pada Pneumatik 2 Auto.

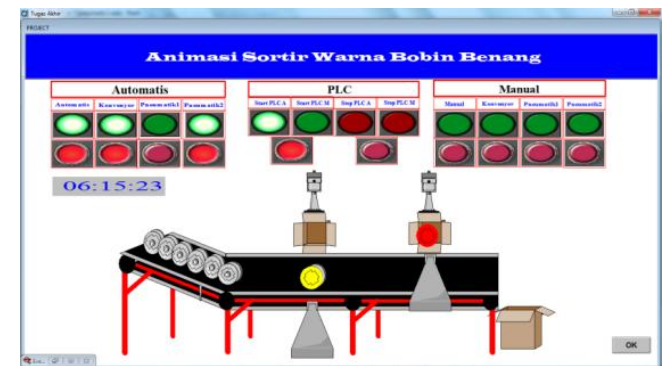

Gambar 42. Proses Awal Sortir Bobbin Merah Secara Auto
Bobin terbawa konveyor sampai menuju ke penambungan warna biru tanpa terdeksi oleh kedua sensor Fiber optic.

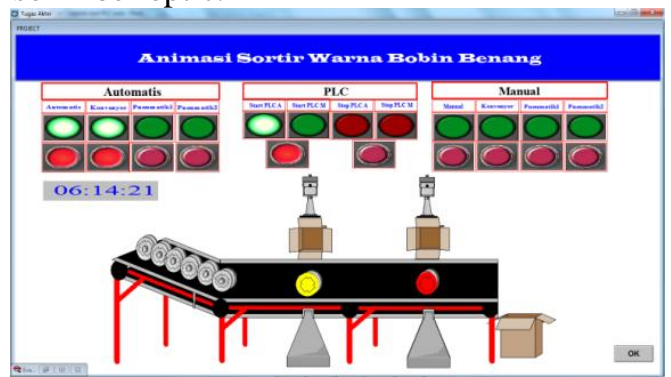

Gambar 43. Proses sortir Bobbin Biru Secara Auto

\section{PENUTUP}

\section{Kesimpulan}

Berdasarkan uji coba, pengukuran dan pembahasan dalam pembuatan alat ini dapat diambil kesimpulan :

- Sensor Fiber Optic memanfaatkan intensitas pantulan cahaya sesuai dengan panjang gelombang warna pada bobbin.

- Pembuatan ladder diagram pada PLC dengan dilakukan secara berurutan sehingga dapat menjalankan sistem dengan otomatis.

- SCADA digunakan untuk melakukan pengamatan dan Sarana untuk mengendalikan / merubah keadaan suatu peralatan.

- Solenoid Valve Berfungsi sebagai media pengatur arah masuk atau keluarnya udara bertekanan untuk mendorong Silinder Pneumatik maju ataupun mundur.

- Pneumatik bekerja dengan sistem ganda,yaitu saat terjadi dorongan maju, udara bertekanan akan mengalir dari pangkal silinder ke ujung silinder, dan saat terjadi dorongan mundur, akan terjadi sebaliknya

\section{Saran}

Sebagai penutup dalam pembuatan alat ini, penulis akan menyampaikan saran sebagai berikut :

- Penggunaan Sensor fiber Optic BF5R lebih memudahkan pengguna dalam mensetting sensor Fiber Optic tersebutkarena sensor tersebut mempunyai jarak penginderaan yang lebih panjang dan dilengkapi dengan layar yang berfungi untuk menampilkan intensitas cahaya yang dipantulkan oleh object

- Menggunakan bahan karet yang dijahit untuk belt konveyor yang berfungsi agar konveyor dapat berjalan dengan stabil,sehingga tidak mengurangi tingkat keakuratan sensor dalam penginderaan 


\section{DAFTAR PUSTAKA}

1. CP1E Programmable Controllers. 2009. CP1E Programmable Controllers Operation Manual. Qld : CP1E Programmable Controllers

2. Denni. 2011. Programmable Logic Control (PLC) http://blogerpoter.blogspot.com /2011/04/ programmable-logic-controller-plcpada.html (Diakses pada 16 Agustus 2014 jam 11.00)

3. Ericson, Damanik. 2014. Pengertian dan Fungsi Pneumatik.

http://ondyx.blogspot.com/2014

/01/pengertian-dan-fungsi-pneumatik.html (Diakses pada 1 September 2014 jam 13.00)
4. Omron, Corp. 2014. Powerful Machine Visualisation .http://industrial. omron. eu/en/ products/catalogue/automation_systems/softwa re/runtime/cxsupervisor/default.html (Diakses pada tanggal 2 September 2014 Jam 9)

5. Petruzella, FD. 1996. Elektronika Industri. Jakarta : Andi.

6. Qtussama. 2012. Kompressor Udara. http://qtussama.wordpress.com/materi-ajar-Xtkr/kompresor-udara/ (Diakses pada 2 September 2014 jam 11.00)

7. Thomas Krist, 1993. Dasar - Dasar Pneumatik. Alih Bahasa Dines Ginting. Jakarta : Erlangga. 